www.jmscr.igmpublication.org Impact Factor 5.244

Index Copernicus Value: 5.88 ISSN (e)-2347-176x ISSN (p) 2455-0450 crossref DOI:_http://dx.doi.org/10.18535/jmscr/v4i6.35

\author{
Journal Of Medical Science And Clinical Research \\ IGM Publication \\ An official Publication of IGM Publication
}

\title{
Presence of Cholesterol Clefts in Chronic tonsillitis
}

\section{Authors \\ Sujatha Nagari ${ }^{1}$, Bharath CH. N.V ${ }^{2}$, Swayam Jothi $S^{3}$, Mani Maran $\mathrm{D}^{4}$, Hemanth Kommuru ${ }^{5}$}

${ }^{1}$ Tutor, Dept of Anatomy, Shri Sathya Sai Medical College \& Research Institute, Kancheepuram Dt

${ }^{2}$ Assistant Professor, Dept of Anatomy, ASRAM, Eluru

${ }^{3}$ Professor \& Head, Dept of Anatomy, SSSMCRI, Kancheepuram Dt

${ }^{4}$ Professor, Dept of Pathology, Tagore Medical College

${ }^{5}$ Tutor, Department of Anatomy, SSSMCRI, Kancheepuram Dt

Corresponding Author

\section{Sujatha Nagari}

Tutor, Department of Anatomy,

Shri Sathya Sai Medical College\& Research Institute, Tiruporur - Guduvancherry Main Road, Ammapettai Village, Sembakkam Post - 603108. Chengalpet Taluk, Kancheepuram District. Chennai - India.

Email:nagarisujatha@gmail.com,kruthika.nagari@gmail.com

\section{ABSTRACT}

In the tonsils, as in the paranasal air sinuses and middle ear, cholesterol ester crystals with foreign body giant cell reaction may result from a focal haemorrhage. Some authorities suggest that cholesterol clefts accumulate in the tissues as a result of degeneration and disintegration of epithelial cells. On the other hand, some authors have suggested circulating plasma lipids as a more likely source, as cholesterol clefts are common in atherosclerotic plaques. In our study 7 cases showed cholesterol clefts, but the significance of cholesterol clefts of tonsils is unknown.

Key words: Cholesterol Clefts, Chronic tonsillitis, Giant cells

\section{INTRODUCTION}

Lymphoid tissues are particularly prominent in the pharynx and nasopharynx, which include tubal, palatine \& lingual tonsils. They form a ring of gut associated lymphoid tissue around the entrance of respiratory \& alimentary tracts, known as Waldeyer's ring ${ }^{[1]}$.

Palatine tonsils are secondary lymphoid organs and the major barrier protecting the digestive tract from the potential invasive microorganisms. They have also been used as sources of lymphoid tissue ${ }^{[3]}$. In the tonsils, as in the paranasal air sinuses and middle ear, cholesterol ester crystals with foreign body giant cell reaction may result from a focal hemorrhage.

Notably, cholesterol clefts are also reported in chronic periapical periodontitis ${ }^{[5]}$, consistent with an inflammatory basis. While the earlier study ${ }^{[2]}$, recognized erythrocytes as a possible source of cholesterol, no mention was made of other cell types potentially contributing to cholesterol deposits including degenerating epithelial cells, connective tissue cells, inflammatory cells and plasma lipoproteins. 
Tangier disease is a familial disorder characterized by orange tonsils, cholesterol deposition in reticulo endothelial cells, abnormal chylomicron remnants, and a marked reduction in high-density lipoproteins ${ }^{[4]}$.

\section{MATERIALS \& METHODS}

One hundred and thirty palatine tonsils surgically removed by ENT Dept of Shri Sathya Sai Medical College, Ammapettai from 65 cases sent to the department of pathology which were reported as chronic tonsillitis were utilized for the study.

Surgically removed bilateral tonsillar tissues were fixed in formalin, embedded in paraffin and prepared slides stained with H\&E. In paraffin sections processed for routine $H \& E$ staining, these crystals are dissolved by the fat solvents used in dehydration and infiltration, leaving needleshaped clefts known as "cholesterol clefts" within cyst walls and cavities ${ }^{[6]}$.

\section{OBSERVATIONS}

Of them 7 cases (6 Male \& 1 female) age ranging between 5-16 years had chronic tonsillitis with Cholesterol Clefts. All 7 cases showed stratified squamous epithelium with underlying lymphoid follicles. The tonsillar crypt contained mixed inflammatory infiltrate lymphocytes with increased vascularity. There was hyperplasia of lymphoid follicles with prominent germinal centres.

Also lined by Acanthotic stratified squamous epithelium containing keratin flakes, cholesterol clefts (Fig: 1 \& Fig: 2) and lymphocytes. Of these one case showed cholesterol cleft with granulation tissue surrounded by multinucleated foreign body type giant cells (Fig: 3) and in another case we notified the keratin calcification (Fig: 4)
Fig 01

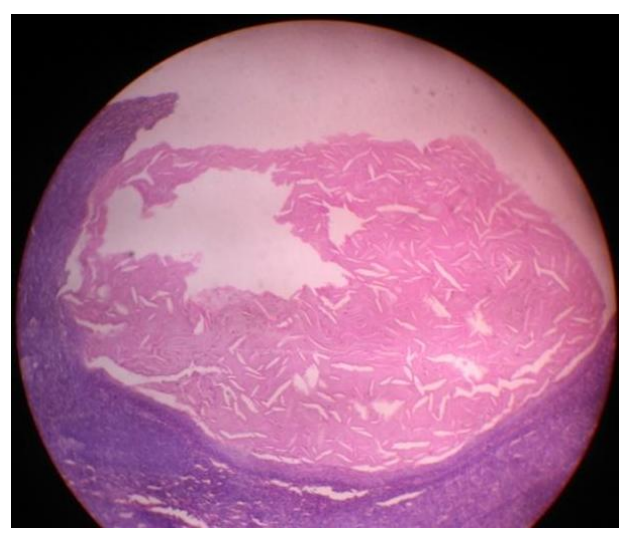

Fig 02

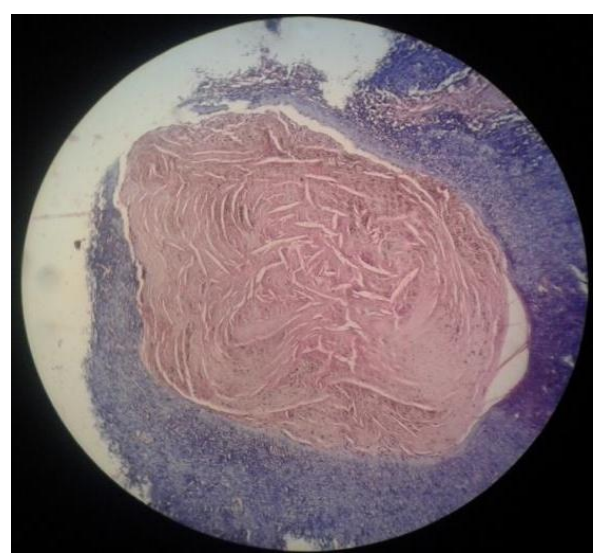

Fig:1 \& 2 Showing crypt wall lined by stratified squamous epithelium and containing keratinous material, cholesterol clefts, and lymphocytes

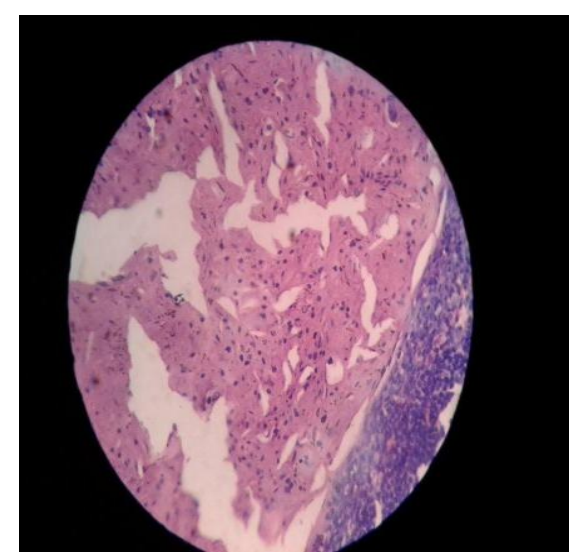

Fig: 3 Showing cholesterol clefts with granulation tissue surrounded by multinucleated foreign body type giant cells 


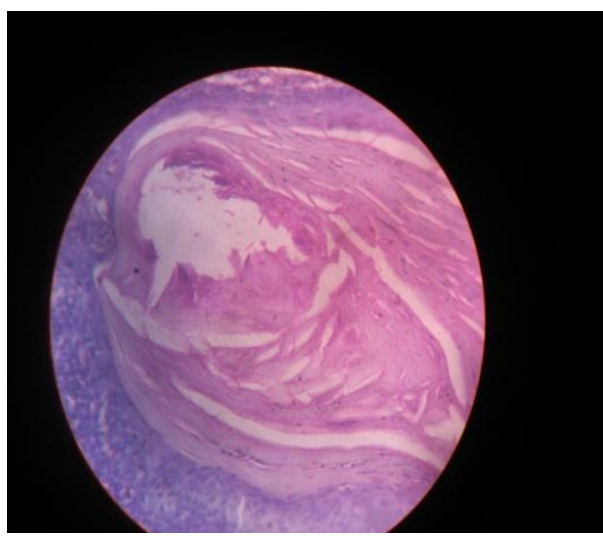

Fig: 4 Showing cholesterol cleft with the keratin calcification

\section{DISCUSSION}

The tonsil consists of a mass of lymphoid follicles supported by a fine connective tissue framework. In the tonsils, as in the paranasal air sinuses and middle ear, cholesterol ester crystals with foreign body giant cell reaction may result from a focal hemorrhage.

In paraffin sections processed for routine $H \& E$ staining, these crystals are dissolved by the fat solvents used in dehydration and infiltration, leaving needle-shaped clefts known as "cholesterol clefts" within cyst walls and cavities ${ }^{[6]}$. This was observed in 7 specimens.

Notably, once cholesterol crystals have been deposited in the cystic wall, they behave as foreign bodies and elicit a foreign body giant cell reaction ${ }^{[7]}$. As a result cholesterol clefts in histological sections are seen surrounded by multinucleated foreign body type giant cells. This was observed in one of the specimens.

Some authorities suggest that cholesterol clefts accumulate in the tissues as a result of degeneration and disintegration of epithelial cells [9]. M. Shear and others have on the other hand, suggested circulating plasma lipids as a more likely source, as cholesterol clefts are common in atherosclerotic plaques and circulating lipids have been identified as the origin of cholesterol in atherosclerosis ${ }^{[6],[8] \text {. }}$

\section{CONCLUSION}

In our study histopathological examination of the tonsils revealed diversity of pathological entities including chronic tonsillitis with fibrosed tonsils, reactive tonsillitis with crypts that show keratinization, cholesterol clefts with granulation tissue surrounded by multinucleated foreign body type giant cells and in one case we notified keratin calcification. Cholesterol clefts accumulate in the tissues as a result of degeneration and disintegration of epithelial cells. The histological study of 200 chronic appendicitis specimens (an area having more lymphoid tissue similar to that of tonsil) never showed the presence of cholesterol clefts. This raises the question whether the presence of cholesterol clefts in tonsil is a causative factor for tonsillar lesions.

\section{REFERENCES}

1. Beasly P. Anatomy of the Pharynx and Oesophagus, In: Basic Sciences. Scott Brown's Orolarvngologv, 5th edn 1987:245-83.

2. Browne, R., 1971. The origin of cholesterol in odontogenic cysts in man. Archives of Oral Biology 16 (1), 107-113.

3. Korsrud FR, Brandtzaeg P. Immune system of human nasopharyngeal and palatine tonsils: histomorphometry of lymphoid components and quantification of immunoglobulin - producing cells in health and disease. Clin Exp Immunol. 1980; 39: 361-70. [PMC free article]PubMed.

4. Leslie Michaels, Henrick B, Hell-Quist Ear, Nose and Throat Histopathology, $1^{\text {st }}$ Edition, Springer Science \& Business Media, 06 Dec 2012, Medical 551 pages

5. Neville, B.W., Damm, D.D., Allen, C.M., Bouquot, J.E., 2002. Chapter 3: Pulpal and Periapical Disease, Oral \& maxillofacial pathology, W.B. Saunders, Philadelphia, pp. 107-136. 
6. Shear, M., 1963. Cholesterol in dental cysts. Oral Surgery, Oral Medicine, Oral Pathology 16 (12), 1465-1473.

7. Shear, M., Speight, P.M., 2007. Cysts of the oral and maxillofacial regions. 4th Edition. Blackwell Pub., Oxford; Ames, Iowa.

8. Skaug, N., 1976. Lipoproteins in fluid from non-keratinizing jaw cysts. European Journal of Oral Sciences 84 (2), 98-105.

9. Thoma, K.H., Goldman, H.M., Gorlin, R.J., 1970. Thoma's Oral pathology. $6^{\text {th }}$ Edition. Mosby, St. Louis. 